\title{
Comparison of Extracts (Ethanol And Aquos Solvents) Muntingia calabura Leaves on Total Phenol, Flavonid And Antioxidant (Ic $\left.\mathbf{c}_{50}\right)$ Properties
}

\author{
Author \\ ${ }^{1}$ Sutrisno Adi Prayitno (Orcid ID. 0000-0002-5116-166X), \\ ${ }^{2}$ Andi Rahmad Rahim (Orcid ID. 0000-0001-5514-6291) \\ Correspondance \\ ${ }^{1}$ Food Technology Study Program, University of Muhammadiyah Gresik \\ ${ }^{2}$ Aquaculture Study Program, University of Muhammadiyah Gresik \\ sutrisnoadi2007@umg.ac.id, andirahmad@umg.ac.id
}

\begin{abstract}
Muntingia calabura plant is a plant in Indonesia that has a variety of functions. It is used as a herbal ingredient to treat certain diseases and also as an antibacterial as well as natural antioxidants. Because inside the leaves there are various bioactive compound that can be used for the sake of herbal making. The purpose of this study is to do early screening of Muntingia calabura leaf extract using ethanol and aquos solvent. The method used in extraction is maceration exaction. The phytochemical analysis performed are total phenols, total flavonoids and antioxidants $\left(\mathrm{IC}_{50}\right)$. The results showed a total phenol in the ethanol extract was $361.22 \mathrm{mg}$ of GAE/g total flavonoids was $42.46 \mathrm{mg} \mathrm{QE} / \mathrm{g}$ and antioxidant activity (IC50) was $131.22 \mu \mathrm{g} / \mathrm{mL}$. At the aquos extract, total phenol was $267.61 \mathrm{mg}$ of $\mathrm{GAE} / \mathrm{g}$, total flavonoids was $16.22 \mathrm{mg}$ QE/g and antioxidant activity $\left(\mathrm{IC}_{50}\right)$ was $129.31 \mu \mathrm{g} / \mathrm{mL}$. By seeing the total phenol and antioxidants in both the extract (ethanol and aquos), the Muntingia calabura leaves have the potential to be used as herbal ingredients and antimicrobial agents.
\end{abstract}

Keywords: Extraction, solvent, phytochemical, antioxidant

Received: 19 May 2020. Accepted: 06 August 2020

\section{Introduction}

Muntingia calabura is a plant that has long been used by people in Indonesia for various health purposes. Often used as a source of food sources and some kind of plant is needed for the world of health or herbs (Isnarianti et al., 2013).The research on Haki (2009) states that in the leaves of it's plant there are active compounds in the form of phytochemical compounds that exhibit antioxidative and antimicrobial activity. It is a type of flavonoids compounds such as: Flavon, Flavonon, Flavan, and Biflavan

The term of phytochemical is a matter that refers to the chemical content in a plant that is essentially included in the chemical of natural materials.

Phytochemical studies can be isolation of natural materials and its classification, chemical structure and its determination, the type of chemical compounds in natural materials up to the level of natural substances (Hanani, 2016). Phytochemical test is necessary to find out the secondary metabolite compounds in each plant studied (Yuliastuti et al, 2017).

Flavonoids are natural antioxidant compounds and have biological activities, such as antioxidants that can delay and stop various oxidation reactions, and able to act as a hydroxyl radical $(\mathrm{OH})$, 
superoxide, and peroxyl radical reduction. In a sample that has a higher total flavonoids compound, it has higher antioxidant activity. The content of flavonoids compounds in plants has a correlation to antioxidant activity (Mbaebie et al., 2012). Flavonoids compounds have a role in antioxidant activity. The position of the $\mathrm{OH}$ compound element and the double bond on flavonoids have a role in increasing antioxidant activity. $\mathrm{OH}$ on the $\mathrm{C}-3$ chain and the double bond between the C-2 chain and the $\mathrm{C}-3$ chain will increase the antioxidant activity (Fridianny et al., 2014). Flavonoids compound are potentially natural compounds as antioxidants that can ward-off free radicals that play a role in the onset of degenerative diseases through a mechanism of destruction of the body's immune system, lipid and protein oxidation (Selawa et al. 2013).

Phenolic compounds are secondary metabolites that play an important role in maintaining health in the human body. The content of phenolic compounds in plants can demonstrate the level of antioxidant activity that can prevent or avoid various diseases by blasting or inhibiting the activity of free radical compounds (Meenakshi et al., 2011). The more number of hydroxyl groups $(\mathrm{OH})$ owned by phenolic compounds, the greater its potential as an antioxidant compound (Pratiwi et al., 2013).

The majority of phenolic compounds dissolve in polar solvents. The use of water as an environmentally friendly polar solvent needs to be optimized by involving non-conventional methods in the extraction of natural materials (Pratiwi et al., 2013). The total content of phenolic can increase during the process of heatgiving (roasting) is suspected due to the effect of hot induction to the exported phenolic compounds (Wani et al., 2016).
The high solubility of phenols is not always found in polar extracts, but also from the phenol structure itself (Septiana and Asnani, 2012).

Compounds that are capable of eliminating, reducing, cleaning, inhibiting the effects of free radical compounds are called antioxidants. Antioxidants stabilize free radicals by supplementing or adding to the deficiency of free radical electrons, and inhibiting or preventing the occurrence of chain reactions from the formation of free radical compounds. In addition, antioxidants are also useful to have the benefit in regulating so that there is no further oxidation process in the body (Selawa et al., 2013).

Antioxidant compounds have an important role in regulating the immune system and the health of the human body, as antioxidant compounds are able to play a role in preventing and reducing the negative effects of oxidants in the body by inhibiting the oxidation of fats or other molecules by inhibiting the mechanism of initiation processes or propagation of oxidative chain reactions and can repair damage to the body cells in the presence of oxygen (Ghavidel et al., 2015; Kim et al., 2011). Antioxidants have been widely used in the process of food processing . The purpose of the use of antioxidants in food processing include to extend the shelf life, especially on foods that contain many unsaturated fatty compounds (Sanda et al., 2015), preventing the process of food oxidation due to the process of changing fats (lipids), vitamins, proteins and carbohydrates due to the influence of reactive oxygen species (Calderón-Oliver et al., 2016).

\section{Method}

\section{Tools and materials}

The tools used are digital scales, aluminium foil, spatula, thermometer, 5 
and $10 \mathrm{ml}$ measuring pipette, vortex, Erlenmeyer 500 and $1000 \mathrm{ml}$, beaker glass, measuring cup $250 \mathrm{ml}$, Shacker (Shacker MaxQ 2000, Barnstead I-LabLine), reaction tube, glass funnel, measuring flask, evaporator device (IKA HB 10 Basic), Vacuum filtration (Refco Manufactured, LTD), and Spectrophotometer Visible (Spectro 20 D Plus). Ethanol 96\%, Akuades, DPPH (2.2difenil-1-Pikrilhidrazil) $0.2 \quad \mathrm{M}$, standardized acid error, Regen Folin Ciocalteau, Na2CO3, NaNO2 5\%, AlCL3 $10 \%, \mathrm{NaOH} 1 \mathrm{M}$, Quercetin.

\section{Maceration extraction (Prayitno et al.,} 2016: Prayitno, et al., 2018)

Maceration extraction with ethanol solvent and water. The concentration of ethanol used is $96 \%$. Comparison of powders with solvents is 1:8 (w/v). Maceration extraction was carried out for 2 days, using a closed erlenmeyer that was placed on a rotary shacker for 3-4 hours and was allowed to stand for 24 hours. And then filtered out and replaced the new sealing fluid with the same volume at the beginning of use. After maceration ends and the filtrate is already attached, the compression is performed filtrate using a rotary evaporator at $40{ }^{\circ} \mathrm{C}$ with a speed of 40-45 rpm. Evaporation rotary process obtained condensed extract, then the extract is analyzed total phenol, total flavonoids and antioxidant activity ( $\mathrm{IC}_{0}$ )

\section{Total Flavonoid (Prayitno, et al., 2018)}

$1 \mathrm{ml}$ of the extract samples were added with $4 \mathrm{ml}$ akuades and $0.3 \mathrm{ml}$ $\mathrm{NaNO} 25 \%$ into the test tube and homogenized, then incubated for five minutes. After 5 minutes then added 0.3 $\mathrm{ml} \mathrm{AlCl} 3$ and incubated for 6 minutes and added $2 \mathrm{ml} \mathrm{NaOH} 1 \mathrm{M}$ and aquades until reaching the volume $10 \mathrm{ml}$ and homogenized. The sample absorption value is measured by a wavelength of 510 $\mathrm{nm}$. The standards used are quercetin 20, 40, 60, 80 and 100 ppm.

\section{Total Fenol (Prayitno., et al 2016)}

Created 5 Series dilution extract. 0.4 $\mathrm{ml}$ of the sample is inserted into the $10 \mathrm{ml}$ flask. Then input the reagents of the Folin ciocalteu as much as $0.4 \mathrm{ml}$ and homogenized. After 5 minutes, mix $4 \mathrm{ml}$ $\mathrm{Na} 2 \mathrm{CO} 3$ 7\%. Add akuades until the volume reaches $10 \mathrm{ml}$ and homogenize. Then incubation for 90 minutes at $230 \mathrm{C}$. Then read absorption absorbantions at $\lambda$ $760 \mathrm{~nm}$. The standards used are acid errors with concentrations of 50, 100, 150, 200 and 250 ppm.

Antioxidant Activity Assay (IC50) by DPPH method (Sharma \& Bhat., 2009: Prayitno dkk., 2018)

The concentrations used were 50, $100,150,200,250 \mathrm{ppm}$. The procedure used is inserting $2 \mathrm{ml}$ of the extract sample into the test tube and added with $1 \mathrm{ml}$ of DPPH solution of $200 \mu \mathrm{M}$, then homogenized and incubated for 30 minutes at $30{ }^{0} \mathrm{C}$. Sample absorption value measured at $517 \mathrm{~nm}$ wavelength

\section{Results and Discussion}

In this research use Muntingia calabura leaf extract. The Muntingia calabura leaves are dried with a dryer cabinet with a temperature of $600 \mathrm{C}$ for $1 \times 24$ hours hours. Then milled using a grinding machine that has a mesh size of 60. A maceration extraction is carried out in a controlled temperature. In early screening conducted on total phenols, total flavonoids and antioxidants ( $\left.\mathrm{IC}_{50}\right)$. The results obtained are seen in table 1 . 
Table 1. Total fenol, flavonoid dan $\mathrm{IC}_{50}$ on leaves extract

\begin{tabular}{lccc}
\hline \multicolumn{1}{c}{ Extract } & $\begin{array}{c}\text { Total Fenol } \\
(\mathrm{mg} \text { GAE/g extract })\end{array}$ & $\begin{array}{c}\text { Total Flavonoid } \\
(\mathrm{mg} \text { QE/g extract })\end{array}$ & $\begin{array}{c}\text { Antioxidant } \\
(\mathrm{IC} 50)(\mu \mathrm{g} / \mathrm{mL})\end{array}$ \\
\hline Ethanol $96 \%$ & $361,22 \pm 0.26$ & $42.46 \pm 0.15$ & $131,22 \pm 0.19$ \\
Aquos & $267,61 \pm 0.13$ & $16.22 \pm 0.21$ & $129,31 \pm 0.12$ \\
\hline
\end{tabular}

\section{Total Phenol}

The total levels of phenol in the extract are expressed in the GAE/g mg. This means that the number of milligrams equivalence acid errors in samples amounted to 1 gram. Total phenol extraction of ethanol gives an average of $361.22 \mathrm{mg}$ of GAE/g while the Aquos extract provides a total level of phenol at 267.61 GAE/g. Differences in solvent have different polarity and type give the result a total of different phenols. The ability of the ethanol solvent is able to penetrate the material cell wall to a deeper than the water. So it is able to do the diffusion of cells and draw bioactive compounds faster and more than with water. It also draws a part of phenolic compounds that are not polar, so it is able to provide a higher total phenol than the aquos. On aquos only draws compounds that are of polar nature only.

Moreover, the length of extraction also gives the influence in the acquisition of the existing phenol compounds in the material. An ethanol solvent is capable of initiating and a particle embezzling process occurs in the material due to the absorption of the solvent, so that the component of the polyphenols in the cell material that has been damaged when the grinding of dry Muntingia calabura leaves can be extracted in a narrow. In addition to the diffusion activity, the ethanol solvent will be diffused to the components of the material deeper into the sample is a pigment that will also be extracted in an ethanol solvent. The volume of the solvent in conducting the extraction also affects the number of compounds to be extracted. Ethanol and aquos solvents have different levels of polarity so they also provide different levels of phenolic compounds. Added by research Deore et al., (2009) states that the phenol compounds that have a hydroxyl group or $\mathrm{OH}$ that are widely or are in a free condition (Aglicon) can produce a phenolic amount or a total of high phenols. Ethanol is an effective solvent for phenolic compounds due to its low level of polarity which causes cell walls in plants that are less polar in nature easily degradated and the phenol compounds are easily out of plant cells (Tiwari et al., 2011). It is also supported by Septiana et al., (2002) which states that semipolar organic solvents are easier to extract phenolic compounds. Therefore, the total content of phenolic in ethanol is higher compared to aquos.

\section{Total Flavoid}

The total rate of phenol in this sample is expressed in $\mathrm{mg}$ of $\mathrm{QE} / \mathrm{g}$, it means that the number equality of quersetin $\mathrm{mg}$ in samples by 1 gram. Ethanol extraction of Total flavonoids has an average of 42.46 $\mathrm{mg}$ of QE/g while the water or aquos extract has an average of $16.22 \mathrm{mg}$ QE/G. The degree of effectiveness between solvent extractions of water and ethanol has a difference. Ethanol is able to provide high levels of flavonoids compared to water. However, the content of flavonoids in many natural substances is determined by the presence of nutrients, UV rays, water and temperature availability or also the conditions and the presence of carbon dioxide in nature. The different types of 
pollutions in the solvent used determine the structure of the compounds that can be extracted. In ethanol extracts that have a higher number of water extracts it is suspected that these ethanol solvents are most likely to also make a withdrawal to the flavonoids compounds that are non polar. However, the Aquos solvent used is binding and pulling on the part of the flavonoids compound, which is polar, so that these solvents or solven produce different amounts of flavonoids. In addition, long extraction is also affecting the type of compounds in the extracted materials.

\section{Antioxidant Activity (IC50)}

The antioxidant activity in the Muntingia calabura leaf extract sample is expressed in $\mathrm{IC}_{50}(\mathrm{ppm})$. This means $\mathrm{IC}_{50}$ is the ability of an antioxidant in samples to reduce free radical compounds of $50 \%$. The antioxidant activity ( $\mathrm{IC}_{50}$ ) of maceration with ethanol has a rate of $130.31 \mu \mathrm{g} / \mathrm{mL}$ while the aquos extract has a IC s0 $_{5}$ kada of $131.22 \mu \mathrm{g} / \mathrm{mL}$. The ethanol and aquos extracts indicate antioxidant activity in the extract samples. This high level of antioxidant activity is supported by the presence of flavonoids in extracts. In addition phytochemical compounds also determine from antioxidant activity. Phytochemical compounds are usually a type of phenols, flavonoids, saponins, tannins, steroids, alcolloids and triterpenoids which all of these compounds are antioxidant.

Antioxidant activity is also supported by the presence of ascorbic acid, tocopherols or pigments in the extracted materials. The antioxidant activity of the ingredients has different structural properties on the phenolic. So that these different phenolic activities can be measured by the additionally DPPH method can also be measured by measuring or inhibit other antioxidant activity. Antioxidant activity in ethanol extract and aquos leaf extract is an antioxidant activity that has a moderate antioxidant category, because the $\mathrm{IC}_{50}$ value produced is $100-150 \mathrm{ppm}$. In Molyneux (2004) mentioned that there are various types of antioxidant properties including antioxidants are strong with the value of $\mathrm{IC}_{50}$ is $<50 \mathrm{ppm}$, strong antioxidant with the value of $\mathrm{IC}_{50}$ is 50 $100 \mathrm{ppm}$, moderate antioxidant with $\mathrm{IC}_{50}$ $100-150 \mathrm{ppm}$ and antioxidant which is weak with $\mathrm{IC}_{50} 150-200 \mathrm{ppm}$ and antioxidant very weak with $\mathrm{IC}_{50}>200$ ppm. The lower the $\mathrm{IC}_{50}$ value generated affects the level of antioxidant activity. If $\mathrm{IC}_{50}$ on the material is low, then the level of its antioxidant activity is increasingly higher. In the analysis of antioxidant activity, color degradation occurs in the test solutions tested. There is a change in the sample wana that is reacted with DPPH from the dense purple color turned yellow.

\section{Conclusion}

Ethanol is able to attract higher phenol compounds and flavonoids than in aquos extracts. However, the antioxidant activity $\left(\mathrm{IC}_{50}\right)$ of ethanol extract is lower compared to aquos extracts.By seeing the total results of phenol and antioxidants in both the extract (ethanol and aquos), the Muntingia calabura leaves have the potential to be used as herbal ingredients and antimicrobial agents.

\section{References}

Calderón-Oliver, M., Escalona-Buendía, H. B., Medina-Campos, O. N., Pedraza-Chaverri, J., Pedroza-Islas, R., \& Ponce-Alquicira, E. 2016. Optimization of the antioxidant and antimicrobial response of the combined effect of nisin and 
avocado byproducts. LWT-Food Science and Technology, 65, 46-52.

Deore, S. L., Khadabadi, S. S., Patel, Q. R., Deshmukh, S. P., Jaju, M. S., Junghare, N. R., \& Jain, R. G. 2009. In vitro antioxidant activity and quantitative estimation of phenolic content of Lagenaria siceraria. Rasayan J Chem,2(1), 129-132.

Fridianny, I., Darmawati, A., \& Sukrasno. 2014. Antioxidant capacities from different polarities extracts of cucurbitaceae leaves using FRAP, $D P P H$ assay and correlation with Phenolic, Flavonoid, Carotenoid Content. Int J Pharm Sci, 6 (2): 858-862.

Ghavidel, R. A., Sheikholeslami, Z., \& Ahmadi, S. 2015. Optimization of extraction the red cabbage extract with ultrasound technology, assisted by response surface method. International Journal of Biosciences (IJB), 6(3), 94-100.

Haki, M. 2009. Efek ekstrak daun talok (Muntingia calabura L.) terhadap aktivitas enzim SGPT pada mencit yang diinduksi karbon tetraklorida (Doctoral dissertation, Universitas Sebelas Maret).

Hanani, E. 2016. Analisis Fitokimia. Penerbit Buku Kedoktorean. EGC. Jakarta. Hal. 2

Isnarianti, R., Wahyudi, I. A., \& Puspita, R. M. 2013. Muntingia calabura L leaves extract inhibits glucosyltransferase activity of Streptococcus mutans. Journal of Dentistry Indonesia, 20(3), 59-63.

Kim, I. S., Yang, M. R., Lee, O. H., \& Kang, S. N. 2011. Antioxidant activities of hot water extracts from various spices. International journal of molecular sciences, 12(6), 4120-4131.
Mbaebie, B. O., Edeoga, H. O., \& Afolayan, A. J. 2012. Phytochemical analysis and antioxidants activities of aqueous stem bark extract of Schotia latifolia Jacq. Asian Pacific Journal of Tropical Biomedicine, 2(2), 118124.

Meenakshi, S., Umayaparvathi, S., Arumugam, M., \& Balasubramanian, T. 2011. In vitro antioxidant properties and FTIR analysis of two seaweeds of gulf of Mannar. Asian Pacific Journal of Tropical Biomedicine, 1(1), S66S70.

Molyneux, P. 2004. The Use Of The Stable Free

Radikal

Diphenylpicrylhydrazyl (DPPH) For Estimating Antioxidant Activity. Journal Science Of Technology, 26 (2) : 211-219.

Pratiwi D., Wahdaningsih S., \& Isnindar. 2013. The Test of Antioxidant Activity from Bawang Mekah Leaves (Eleutherine americana Merr.) using DPPH (2,2-Diphenyl1-Picrylhydrazyl) Method. Trad. Med. J., 18.1 (2013): 10-11

Prayitno, S. A., Kusnadi, J., \& Murtini, E. S. 2016. Antioxidant activity of red betel leaves extract (piper crocatum ruiz \& pav.) by difference concentration of solvents. Research Journal Of Pharmaceutical Biological And Chemical Sciences, 7(5), 1836-1843.

Prayitno, S. A., \& Murtini, E. S. 2018. Karakteristik (Total Flavonoid, Total Fenol, Aktivitas Antioksidan) Ekstrak Serbuk Daun Sirih Merah (Piper crocatum Ruiz \& Pav.). Food Science and Technology Journal (Foodscitech), 1(2), 26-34. 
Sanda, M. A., Zengin, G., Aktumsek, A., \& Cakmak, Y. S. 2015. Evaluation of antioxidant potential of two Daphne species (D. gnidioides and D. pontica) from Turkey. Emirates Journal of Food and Agriculture, 27(6), 488-494.

Selawa, W., Runtuwene, M.R \& Citraningtyas, G. 2013. Kandungan flavonoid dan kapasitas antioksidan total ekstrak etanol daun binahong [Anredera cordifolia (ten)]. PHARMACON, 2(1). $18-22$.

Septiana AT., Muchtadi, D., dan Zakaria, F.R. 2002. Aktivitas antioksidan ekstrak diklorometana dan air jahe pada asam linoleat. Jurnal Teknol dan Industri Pangan 13 (2):105-110.

Septiana, A. T., \& Asnani, A. 2016. Kajian sifat fisikokimia ekstrak rumput laut coklat Sargassum duplicatum menggunakan berbagai pelarut dan metode ekstraksi. Agrointek, 6 (1), 22-28.

Sharma, O. P., \& Bhat, T. K. (2009). DPPH antioxidant assay revisited. Food chemistry, 113(4), 1202-1205.

Tiwari, P., Kumar, B., Kaur G., Kaur, H., and Kaur, M. 2011. Phytochemical Screening and Extraction : A review. J Int Pharm Sci 1 : 98-106

Wani, I.A., Gani, A., Tariq, A., Sharma, P., Farooq, P., Masoodi, A. \& Wani, H.M. 2016. Effect of roasting on physicochemical, functional and antioxidant properties of arrowhead (Sagittaria sagittifolia L.) flour. Food Chemistry. 197(1): 345-352.

Yuliastuti, F., Lutfiyati, H., Dianita, P. S., Hapsari, W. S., \& Pradani, M. P. K. 2017. Identifikasi Kandungan
Fitokimia dan Angka Lempeng Total (ALT) Ektrak Daun Landep (Barleria prioritis L). URECOL, 389-396. 